\title{
The diversity of Indian Ocean Heterotardigrada
}

\author{
Maria GALLO*, Rossana D'ADDABBO, Cristiana DE LEONARDIS, Roberto SANDULLI \\ and Susanna DE ZIO GRIMALDI
}

Dipartimento di Zoologia, Università di Bari, Via Orabona, 4 - 70125 Bari, Italy

*e-mail corresponding author: m.gallo@biologia.uniba.it

\begin{abstract}
Information about Indian Ocean tardigrades is quite scarce and in most cases refers to species in coastal coralline sediment and occasionally in abyssal mud. The present data concern species found in the intertidal sand of Coco and La Digue Islands in the Seychelles, previously unsampled for tardigrades, as well as species in subtidal sediment found at depths ranging between 1 and 60 $m$ off the shores of the Maldive Atolls. These sediments are all very similar and consist of heterogeneous coralline sand, moderately or scarcely sorted. Sixteen species (three new to science) were found in the Seychelles, belonging to Renaudarctidae, Stygarctidae, Halechiniscidae, Batillipedidae and Echiniscoididae. Diversity and evenness data are also interesting, with maximum values of $H^{\prime}=$ 2.59 and of $J=0.97$. In the Maldives 25 species were found (two new to science) belonging to Neostygarctidae, Stygarctidae, Halechiniscidae and Batillipedidae. Such a number of species, despite the low percentage of tardigrade fauna (only $0.6 \%$ of the total meiofauna), contributes to the high values of both diversity and evenness, with $H^{\prime}$ ranging between 1.5 and 2.6 and J between 0.6 and 1. The Indian Ocean tardigrade fauna currently numbers 31 species of Arthrotardigrada and 2 species of Echiniscoidida. In the present study, Arthrotardigrada are the most abundant and all the families are present except Neoarctidae. Halechiniscidae is present with all the sub-families (except Euclavartinae), thus contributing to the high diversity values. Furthermore, 18 species, representing more than 50\% of the total marine tardigrade fauna, are new records for the Indian Ocean, including five species new to science.
\end{abstract}

Keywords: Tardigrada, Heterotardigrada, Seychelles, Maldives, biodiversity

\section{INTRODUCTION}

Although the overall bibliography of marine tardigrades is quite limited, references on the species found in the Indian Ocean are numerous and mainly related to Arthrotardigrada from abyssal mud and coastal coralline sand from Madagascar, the Mozambique Channel, the Comoros Islands, Mauritius and the Maldives (RenaudDebyser 1965a, b; Renaud-Mornant 1974, 1975, 1979a, b, 1981, 1984, 1987; Kristensen \& Renaud-Mornant 1983; Grimaldi de Zio et al. 1987; de Zio Grimaldi et al. 1999).

Our new findings of several tardigrade species in the intertidal sand of the Seychelles Islands and in subtidal sand along coral reefs of the Maldives Archipelago add further information to previous data.

\section{METHODS}

The Seychelles sediment studied for the tardigrade fauna was sampled from the intertidal zone in 1 site at Coco and 4 sites at La Digue Islands (Banane, Cocos, La Rèunion, La Source à Jean) in March 2004. In the Maldives most of the samples were collected by SCUBA diving from 14 sites, during the April 2004 Scientific cruise "Albatros", at depths ranging from 1 to $60 \mathrm{~m}$ along the external coral reefs and in 2 caves of four atolls (South Male, North Ari, South Ari, and Felidhoo). Figure 1 shows the whole sampling area.
Sediment meiofauna samples were immediately fixed with $5 \%$ formalin/seawater and the animals extracted from sand using the multiple decantations technique and retained on a $42 \mu \mathrm{m}$ mesh sieve.

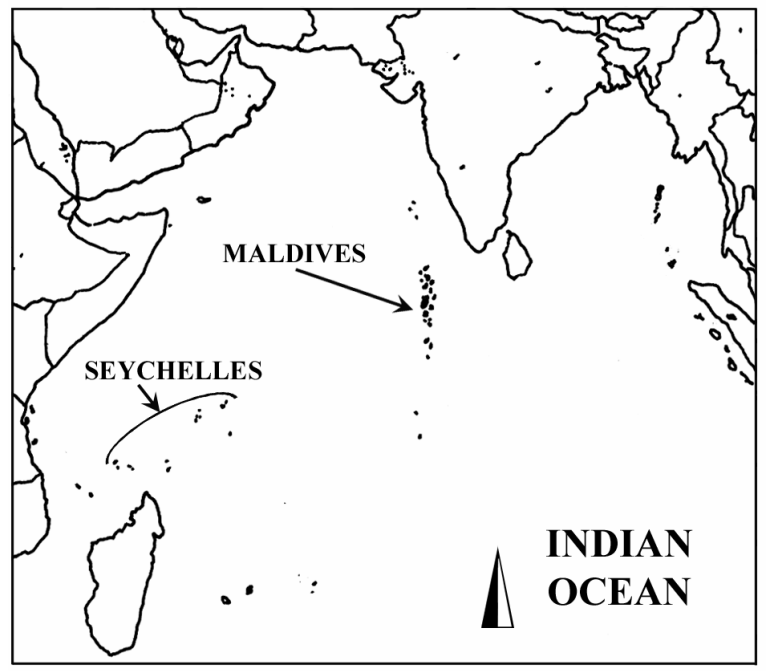

Fig. 1. Location map of Indian Ocean.

Following slow dehydration in alcohol-glycerol solutions, permanent mounts were made either in Kaiser's glycerol-gelatin or Hoyer's fluid (Higgins \& Thiel 1988). Contrast phase and interference contrast micros- 
Tab. 1. Tardigrada species, number of specimens, density and diversity per site of the Seychelles Islands. CS = coarse sand; $\mathrm{MS}=$ medium sand; MFS = medium fine sand; FS = fine sand; $\mathrm{H}^{\prime}=$ Shannon-Wiener index; $\mathrm{J}=$ Pielou's index.

\begin{tabular}{|c|c|c|c|c|c|}
\hline & \multirow[t]{2}{*}{ Cocos Island } & \multicolumn{4}{|c|}{ La Digue Island } \\
\hline & & $\begin{array}{c}\text { Anse } \\
\text { Banane } \\
\end{array}$ & $\begin{array}{l}\text { Anse } \\
\text { Cocos }\end{array}$ & $\begin{array}{c}\text { Anse } \\
\text { La Rèunion }\end{array}$ & $\begin{array}{c}\text { Anse } \\
\text { La Source à Jean }\end{array}$ \\
\hline Site & 1 & 2 & 3 & 4 & 5 \\
\hline Depth (m) & 0 & 0 & 0 & 0 & 0 \\
\hline Mean Grain Size $(\Phi)$ & 0.5 & 2 & 1.5 & 2.5 & 1.5 \\
\hline Sediment type & CS & MFS & MS & FS & MS \\
\hline \multicolumn{6}{|l|}{ Taxon } \\
\hline $\begin{array}{l}\text { Stygarctidae } \\
\text { Stygarctus lambertii Grimaldi de Zio et al. } 1987\end{array}$ & & & & & 1 \\
\hline $\begin{array}{l}\text { Renaudarctidae } \\
\text { Renaudarctus psammocryptus Kristensen \& Higgins } 1984 \\
\text { Renaudarctus n. sp. }\end{array}$ & & & & & $\begin{array}{l}3 \\
1\end{array}$ \\
\hline Halechiniscidae & & & & & \\
\hline Dipodarctus subterraneus (Renaud-Debyser 1959) & 2 & & & & \\
\hline Florarctus antillensis Van der Land 1968 & 22 & & & & 4 \\
\hline Florarctus hulingsi Renaud-Mornant 1976 & & 3 & & & \\
\hline Florarctus n. sp. & & 11 & & & \\
\hline Wingstrandarctus intermedius Renaud-Mornant 1967 & & & 1 & & 3 \\
\hline Halechiniscus greveni Renaud-Mornant \& Deroux 1976 & 1 & & & & \\
\hline Styraconyx nanoqsunguak Kristensen \& Higgins 1984 & 1 & & & & \\
\hline Styraconyx sardiniae D'Addabbo Gallo et al. 1989 & 2 & & & & \\
\hline Styraconyx tyrrhenus D'Addabbo Gallo et al. 1989 & 1 & & & & \\
\hline Batillipedidae & & & & & \\
\hline Batillipes pennaki Marcus 1946 & & 2 & 1 & 3 & 1 \\
\hline Batillipes n. sp. & & 1 & & 2 & 6 \\
\hline Echiniscoididae & & & & & \\
\hline Anisonyches diakidius Pollock 1975 & 2 & 1 & & & 3 \\
\hline Anisonyches mauritianus Grimaldi de Zio et al. 1987 & 1 & & & & \\
\hline Total & 32 & 18 & 2 & 5 & 22 \\
\hline Species number & 8 & 5 & 2 & 2 & 8 \\
\hline Total Density (n. ind. $\cdot 10 \mathrm{~cm}^{2}$ ) & 52 & 29 & 3 & 8 & 35 \\
\hline $\mathrm{H}^{\prime}$ & 1.75 & 1.68 & 1 & 0.97 & 2.74 \\
\hline $\mathrm{J}$ & 0.58 & 0.72 & 1 & 0.97 & 0.91 \\
\hline
\end{tabular}

copy (Leica DM 2500) were used to perform identification and taxonomic studies on tardigrades. Shannon-Wiener diversity index $\left(\mathrm{H}^{\prime}\right)$ and Pielou's index $\left(\mathrm{J}^{\prime}\right)$ of equitability (evenness) were calculated. Sediment samples were analysed for particle size.

\section{RESULTS}

The sediment consists of white coralline sand, ranging between 0.25 and $2.5 \Phi$, usually moderately and poorly sorted (Tabs 1 and 2).

Tardigrades always represent a very modest fraction of the meiofauna; nevertheless, they show interesting values of diversity and evenness at the studied sites.

Sediment from the Seychelles Islands, the first ever sampled for tardigrades, contained 16 species, belonging mainly to Halechiniscidae but also to Renaudarctidae, Stygarctidae, Batillipedidae and Echiniscoididae (Tab. 1). The highest density was recorded at Cocos Island (site 1) with 52 individuals $10 \mathrm{~cm}^{-2}$. Diversity $\left(\mathrm{H}^{\prime}\right)$ and Evenness $(\mathrm{J})$ indices are remarkably high at Anse La Source à Jean, 2.74 and 0.9 respectively (Fig. 2). At the same site, all the collected and identified specimens (22) belong to five families.
The finding of 3 specimens, two females, and one $2^{\text {nd }}$ stage larva, of Renaudarctus psammocriptus, and 1 male specimen of Renaudarctus $\mathrm{n}$. sp. is quite remarkable. Only one adult female of Stygarctus lambertii and of Anysoniches mauritianus were found, for the first time on the island of Mauritius, from "Belle Mer" beach. Only two adult females of Styraconyx sardiniae and one $2^{\text {nd }}$ stage larva of Styraconyx tyrrhenus were recorded. Both species were previously known only from the Mediterranean Sea. The Halechiniscidae family is present with 9 species, among which one is new to science (Florarctus n. sp.). The Batillipedidae family has representatives only in fine sand, with 7 specimens (one adult female, three $2^{\text {nd }}$ stage larvae, three $1^{\text {st }}$ stage larvae) of Batillipes pennaki, collected in 4 sites and 9 specimens of a new Batillipes species (two adult female, five $2^{\text {nd }}$ stage larvae, and two $1^{\text {st }}$ stage larvae) collected in 3 sites. The family Echiniscoididae is represented by two species, one previously found on Mauritius ( $A$. mauritianus), as noted above, and Anysoniches diakidius, with one $1^{\text {st }}$ stage larva and three $2^{\text {nd }}$ stage larvae, already known for the Atlantic and the Pacific Ocean. 


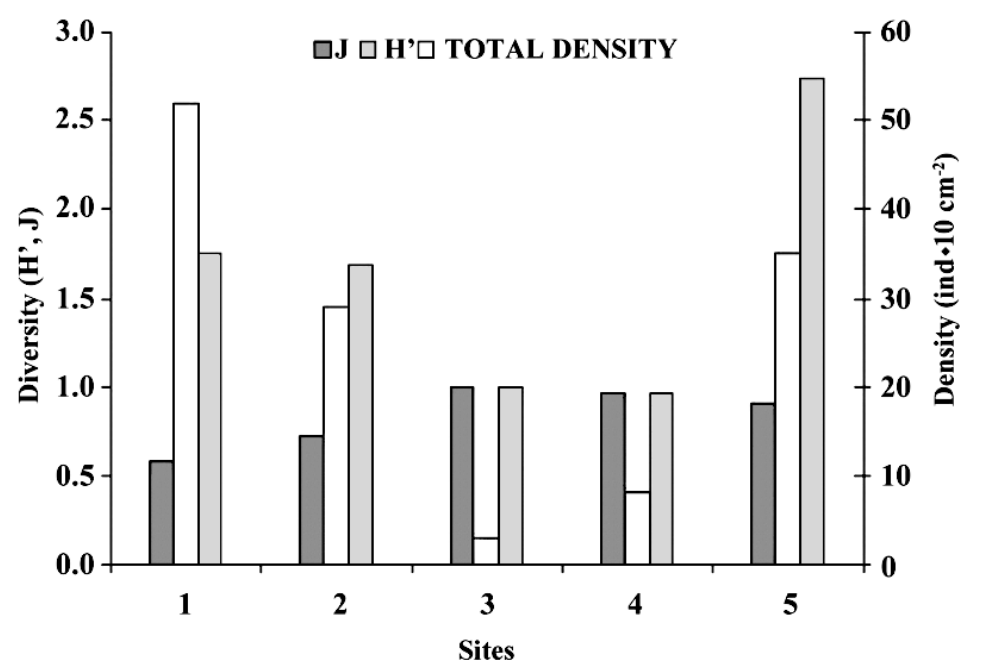

Fig. 2. Density and diversity of Seychelles marine tardigrade fauna.

Tab. 2. Tardigrada species, number of specimens, density and diversity per site of the Maldivian Islands. CS = coarse sand; MS = medium sand; $\mathrm{H}^{\prime}=$ Shannon-Wiener index; $\mathrm{J}=$ Pielou's index .

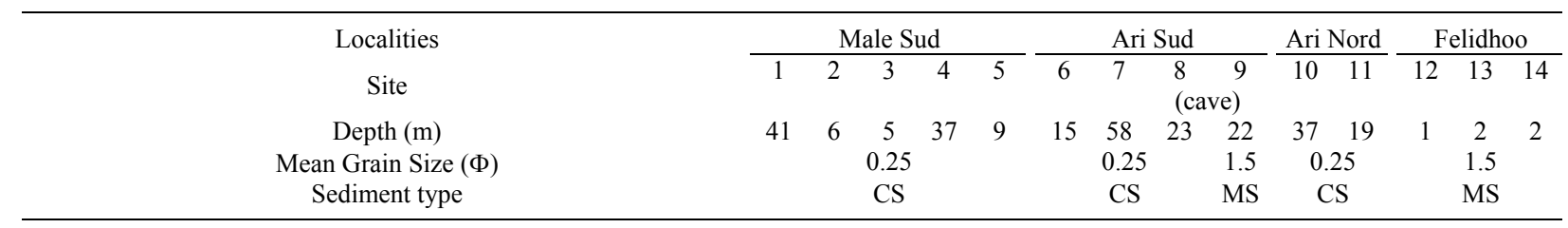

Neostygarctidae

Neostygarctus acanthophorus Grimaldi de Zio et al. 1982

2

$\begin{array}{ll}4 & 1\end{array}$

\section{Stygarctidae}

Parastygarctus renaudae Grimaldi de Zio et al. 1987

Megastygarctides $\mathrm{n}$. sp.

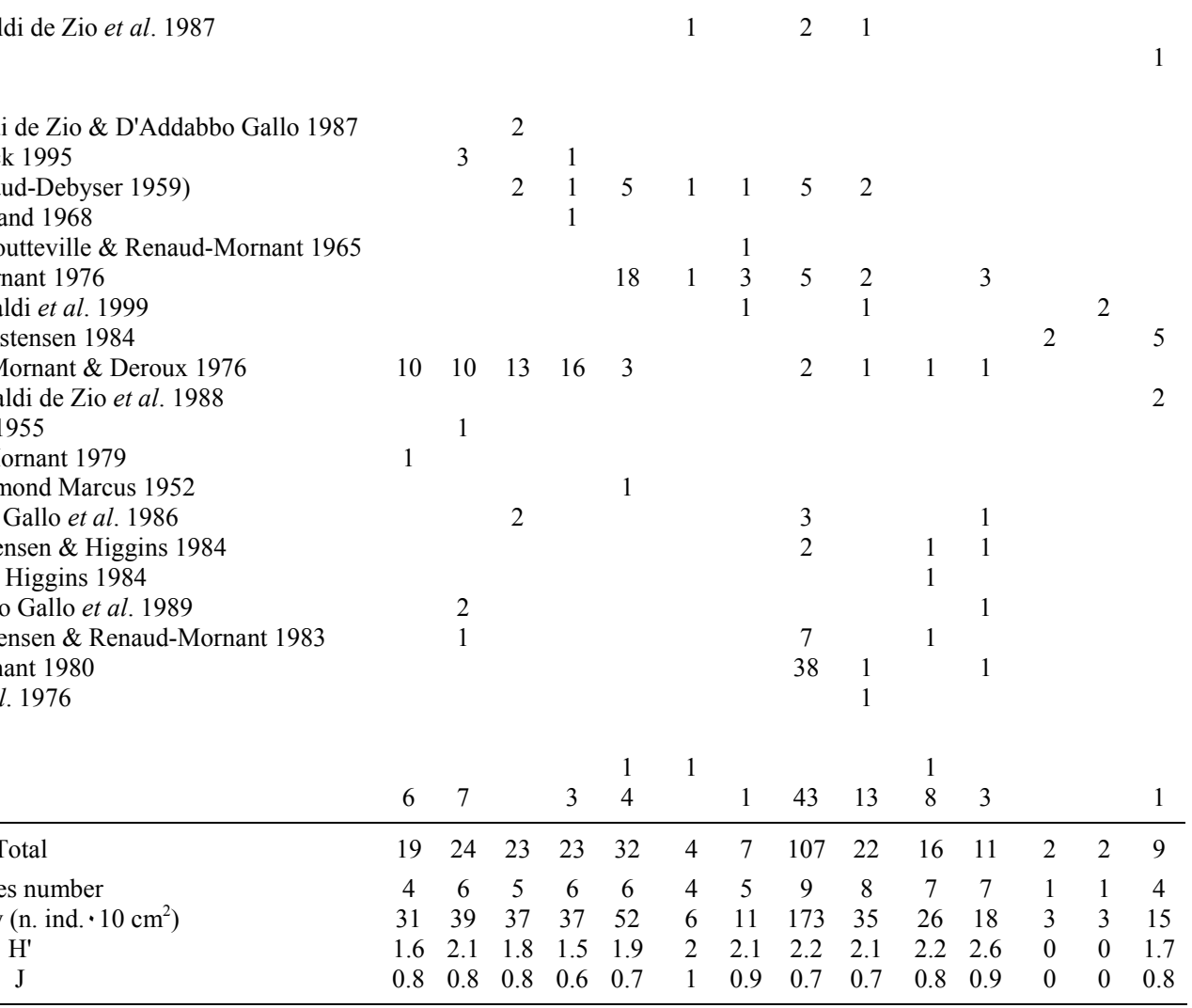

Archechiniscus minutus Grimaldi de Zio \& D'Addabbo Gallo 1987

Dipodarctus anaholiensis Pollock 1995

Dipodarctus subterraneus (Renaud-Debyser 1959)

Florarctus antillensis Van der Land 1968

Florarctus heimi Delamare Deboutteville \& Renaud-Mornant 1965

Florarctus hulingsi Renaud-Mornant 1976

Florarctus pulcher de Zio Grimaldi et al. 1999

Wingstrandarctus corallinus Kristensen 1984

Halechiniscus greveni Renaud-Mornant \& Deroux 1976

Halechiniscus paratuleari Grimaldi de Zio et al. 1988

Halechiniscus perfectus Schulz 1955

Halechiniscus tuleari Renaud-Mornant 1979

Orzeliscus belopus Du Bois Reimond Marcus 1952

Raiarctus variabilis D'Addabbo Gallo et al. 1986

Styraconyx nanoqsunguak Kristensen \& Higgins 1984

Styraconyx qivitoq Kristensen \& Higgins 1984

Styraconyx tyrrhenus D'Addabbo Gallo et al. 1989

Tholoarctus natans natans Kristensen \& Renaud-Mornant 1983

Tanarctus gracilis Renaud-Mornant 1980

Tanarctus velatus Mc Kirdy et al. 1976

Batillipedidae

Batillipes pennaki Marcus 1946

Batillipes n. sp. 


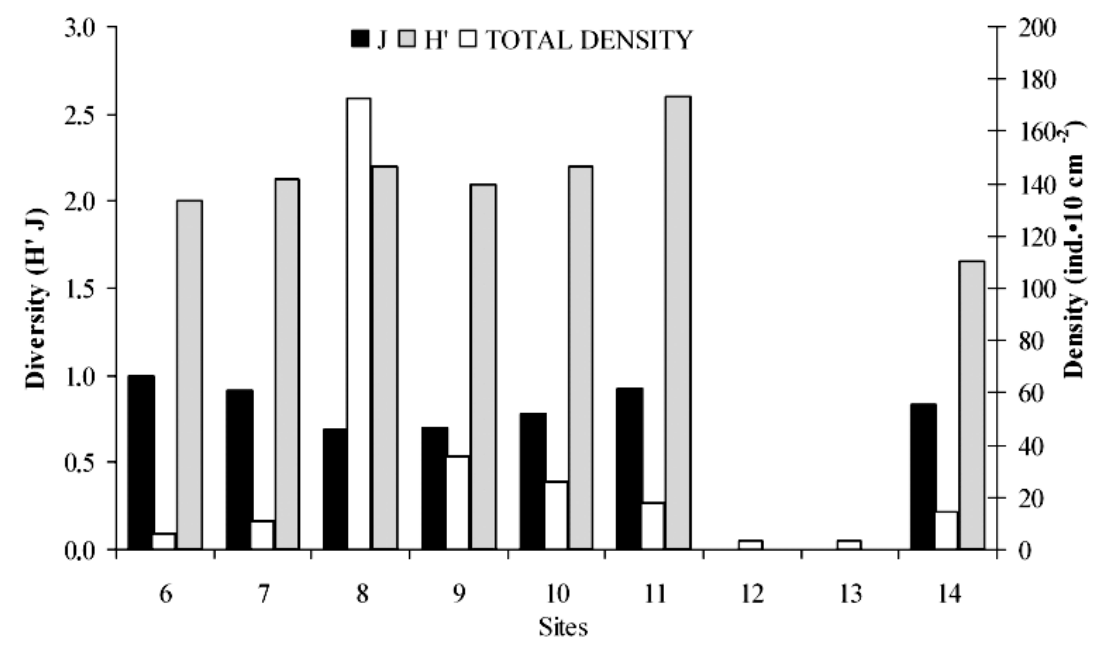

Fig. 3. Density and diversity of Maldivian marine tardigrade fauna.

In the Maldives Islands, 25 species were found from 4 families: Neostygarctidae (1 species), Stygarctidae (2 species), Halechiniscidae (20 species) and Batillipedidae with 2 species, one of which is new to science (Tab. 2 ). The highest density was recorded at the Bulhaa Lhohi cave (South Ari atoll, site 8) with 173 individuals $\cdot 10 \mathrm{~cm}^{-2}$ (Fig. 3). The highest values of $\mathrm{H}^{\prime}$ (2.6) and $\mathrm{J}$ (1) were respectively recorded at site 11 and site 6 (Fig. 3).

Neostygarctus acanthophorus (Neostygarctidae) is present in 4 sites with two adult males, three adult females, four $2^{\text {nd }}$ stage larvae, and one $1^{\text {st }}$ stage larva. The Stygarctidae were present in 4 sites with only 4 specimens (one adult male, one adult female, one $1^{\text {st }}$ stage larva and one $2^{\text {nd }}$ stage larva), of Parastygarctus renaudae, previously recorded on Mauritius, and with only one specimen ( $2^{\text {nd }}$ stage larva) of Megastygarctides n. sp., at site 14 of Fotteyo Finolhu (Felidhoo Atoll), collected at $2 \mathrm{~m}$ depth. In the present study, the Halechiniscidae family markedly contributes to the high values of diversity, being present with several species and with all its sub-families (except Euclavarctinae). This family is present in all sites studied, and is the exclusive taxon in site 12 and 13. Only one specimen (adult female) of Tanarctus velatus was collected in the cave of site 9, and only one specimen (adult female) of Florarctus heimi was sampled at site 7 . The family Batillipedidae, represented by 2 species at 11 sites, is also a dominant component of the tardigrade fauna. One of them, found at 10 sites with 89 specimens, is a new species still to be described.

\section{DISCUSSION}

The present data add faunistic and biogeographic information about the distribution of marine tardigrade fauna. The number of species in the Indian Ocean to date represents more than $1 / 3$ of the known species of marine Heterotardigrada with both the Arthrotardigrada and Echiniscoidea orders. In the present study, the Arthrotardigrada show the highest densities, with Halechiniscidae strongly contributing to the high values of the diversity. Excluding the Neoarctidae family, all the other known families are present in the Indian Ocean. The finding of $R$. psammocriptus, previously recorded in the Atlantic and Pacific Oceans, Renaudarctus n. sp., T. velatus, and of $F$. heimi, previously found only in the Pacific Ocean, and, finally, of $N$. acanthophorus, Archechiniscus minutus, Halechiniscus paratuleari, S. sardiniae and S. tyrrhenus, previously known only in the Mediterranean Sea, is very remarkable.

The total number of known marine heterotardigrade species to date is $170 ; 65$ found in the Indian Ocean (38\% of world marine tardigrade fauna), 79 in the Mediterranean Sea (46\%), 76 in the Atlantic Ocean $(45 \%)$, and 61 in the Pacific Ocean (36\%). There are several species in common in various basins; for example, the Mediterranean Sea and Indian Ocean share 40 species (about $50 \%$ of total Mediterranean tardigrade fauna, and more than $60 \%$ of total Indian Ocean tardigrades), and the Atlantic Ocean and Mediterranean Sea share 37 species. Furthermore, the theory of plate tectonics might partly explain the existence of a rather high number of cosmopolitan species such as Parastygarctus sterreri Renaud Mornant, 1970, Stygarctus bradypus Schulz, 1951, Archechiniscus marci Schulz, 1953, Florarctus antillensis Van der Land, 1968, Wingstrandarctus corallinus, Halechiniscus perfectus, Halechiniscus remanei Schulz, 1955, Orzeliscus belopus, Styraconyx craticulus (Pollock 1983), Styraconyx sargassi Thulin, 1942, Tholoarctus natans natans, Batillipes mirus Richters, 1909, B. pennaki and A. diakidius.

\section{REFERENCES}

de Zio Grimaldi, S., A. Lamarca, M. D'Addabbo Gallo \& R. Pietanza. 1999. Florarctinae of Asdhu Island, Maldive, Indian Ocean (Tardigrada, Heterotardigrada). Ital. J. Zool., 66: 383-391. 
Grimaldi de Zio, S., M. D'Addabbo Gallo, M.R. Morone De Lucia \& L. D'Addabbo. 1987. Marine Arthrotardigrada and Echiniscoididae (Tardigrada: Heterotardigrada) from the Indian Ocean. Boll. Zool., 4: 347-357.

Higgins R.P. \& H. Thiel. 1988. Introduction to the study of meiofauna. Smithsonian Institution Press, Washington D.C.: 488 pp.

Kristensen, R.M. \& J. Renaud-Mornant. 1983. Existence d'Arthrotardigrades semi-benthiques de genre nouveaux de la sous famille des Styraconyxinae, subfam. nov. Cah. Biol. Mar., 24: 337-354.

Renaud-Debyser, J. 1965a. Parastygarctus higginsi n. g., n. sp. Tardigrade marin interstitiel de Madagascar. C.R. Acad. Sci. Paris, 260: 955-957.

Renaud-Debyser, J. 1965b. Etude sur un Stygarctidé (Tardigrada) nouveau de Madagascar. Bull. Soc. Zool. France, 90: 31-38.

Renaud-Mornant, J. 1974. Une nouvelle famille de Tardigrades marins abyssaux: les Coronarctidae fam. nov. (Heterotardigrada). C.R. Acad. Sci. Paris, Ser. D, 278: 3087-3090.
Renaud-Mornant, J. 1975. Deep sea Tardigrada from the "Meteor" Indian Ocean Expedition. "Meteor" Forsh. Ergebnisse; Reid B, 21: 54-61.

Renaud-Mornant, J. 1979a. Tardigrades marines de Madagascar. I. Halechiniscidae et Batillipedidae. Bull. Mus. natn. Hist. nat. Paris, 1: 257-277.

Renaud-Mornant, J. 1979b. Tardigrades marins de Madagascar. II. Stygarctidae et Oreellidae. III. Considérations écologiques générales. Bull. Mus. natn. Hist. nat. Paris, 1: 339-351.

Renaud-Mornant, J. 1981. Raiarctus colurus n. g., n. sp., et $R$. aureolatus n. sp., Tardigrades (Arthrotardigrada) marins nouveaux de sédiments calcaires. Bull. Mus. natn. Hist. nat. Paris, 3: 512-522.

Renaud-Mornant, J. 1984. Halechiniscidae (Heterotardigrada) de la campagne Benthedi, canal de Mozambique. Bull. Mus. natn. Hist. nat. Paris, 6: 67-88.

Renaud-Mornant, J. 1987. Bathyal and abyssal Coronarctidae (Tardigrada), descriptions of new species and phylogenetical significance. In: R. Bertolani (Ed.), Biology of Tardigrades. Selected Symposia and Monographs U.Z.I., 1. Mucchi, Modena, Italy: 253-260. 